\title{
11. Logistical virulence, migrant exposure, and the underside of Singapore's model pandemic response
}

William Jamieson

At the outset of the COVID-I9 pandemic, Singapore was lauded for its early declaration of a public health emergency, its assiduous testing regime and track and trace system, and its quarantining of positive cases. However, the initial exemplarity of its pandemic response had been savagely undermined by April 2020 (Chew et al. 2020). Outbreaks in migrant worker dormitories had gone undetected and had to be contained by stringent lockdowns. As the infection spread, it quickly became apparent that it was nigh on impossible for migrant workers to effectively socially distance in their dorms, quartered I 5-20 to a room, as well as sharing toilets, kitchens, and dining areas (Koh 2020). Migrant workers were decanted from their dormitories to disperse dense populations of healthy workers from infected dorms and quarantine infected workers. These temporary measures took equally utopian and dystopian turns; some workers were lodged in their own Housing Development Board flats, which are state-administered public housing usually out of reach for this segregated class of worker; some others were relocated to ocean liners, with separate ships for the healthy and for the infected, inverting the bygone practice of plague ships into a parody of the city-state's own attitude towards its workers: out of sight, out of mind. While these measures were eventually effective, Singapore's overall number of infections swelled to 56,000 by late August 2020; over $90 \%$ of those cases were from migrant worker dormitories (CNA 2020; Han 2020).

This chapter seeks to locate the unique exposure of migrant workers to disease during the pandemic within the city-state's peculiar political economy and the construction of the migrant worker as an already pathological subject requiring containment, both spatially and logistically. Migrant workers are not only a stigmatised source of cheap labour

How to cite this book chapter:

Jamieson, William. 2022. 'Logistical virulence, migrant exposure, and the underside of Singapore's model pandemic response'. In: Shin, Hyun Bang; Mckenzie, Murray; and Oh, Do Young (eds) COVID-I9 in Southeast Asia: Insights for a post-pandemic world. London: LSE Press, pp. I 3 I-I40. DOI: https://doi.org/IO.3 I389/lsepress.cov.k License: CC BY 4.०. 


\section{Figure 11.1. Tuas View Dormitory}

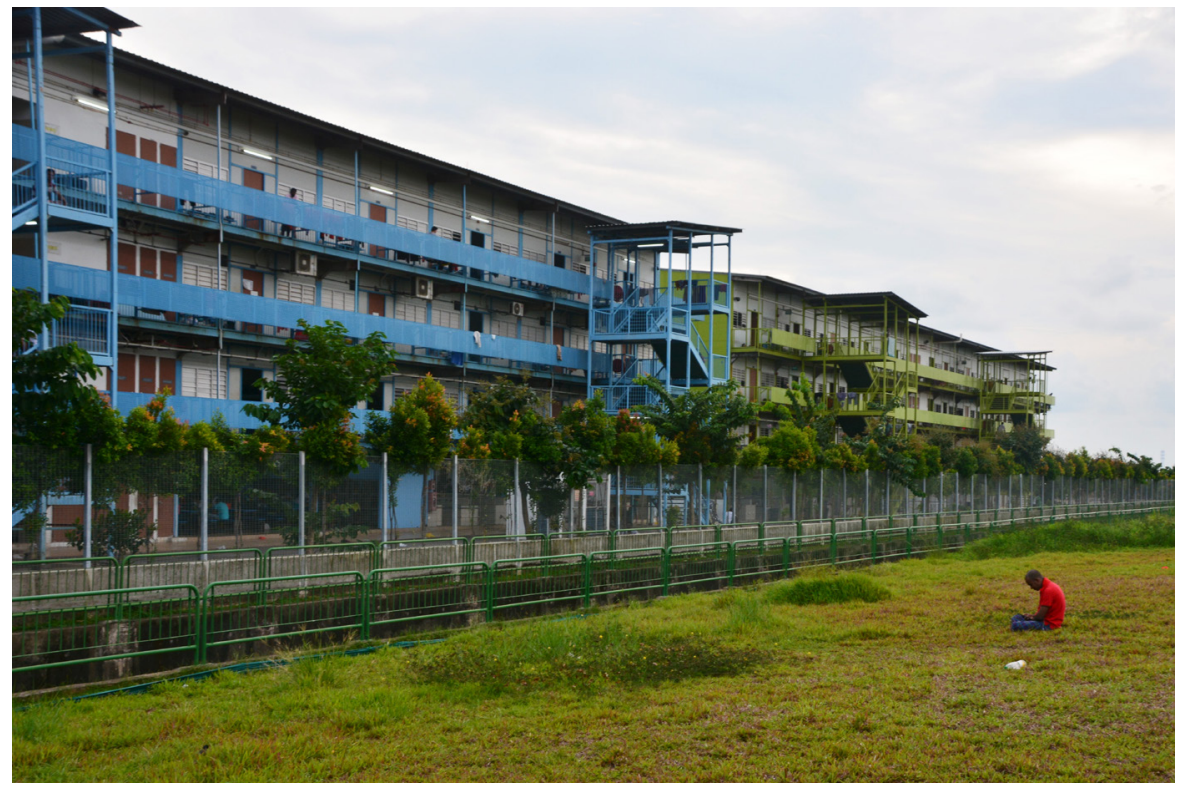

Source: Robert John (2019).

within the city-state, their presence configured through recurrent moral panics by the state and the media, but also the subjects of a covert and problematic model of logistical citizenship that the Singaporean state requires for its reproduction. The initial exemplarity of Singapore's pandemic response was starkly unmasked to reveal what Yea (2020) has termed the 'institutionalised neglect' of its migrant workers; a study in 2017 found migrant workers at higher risk of infectious disease than the general population, owing to a combination of socio-economic status, countries of origin, and living conditions, as well as language and financial barriers to healthcare (Sadarangani, Lim, and Vasoo 20I7). Singapore as a model global city has been undergirded by stark disparities in its subjects of governance: citizen, expat, and migrant worker (Yeoh 2006). While others have rightly responded to the exposure of the condition of migrant workers during the pandemic as an appalling disparity that needed to be ameliorated, this chapter will identify the mechanisms through which the vulnerability of migrant workers in Singapore stemmed from the haphazard construction of logistical citizenship, a biopolitical category the city-state relies upon to achieve its vaunted model of governance. This chapter aims to contribute towards critical geographies of logistics by centring the biopolitics of 
citizenship. It begins with an outline of Singapore's logistical state, followed by a discussion of the evolving governance of migrant workers in Singapore. It then concludes with an analysis of Singapore's implicit model of logistical (non-)citizenship, a model of logistical violence that has in turn ripened into logistical virulence.

\section{Singapore as a logistical state}

Recent scholarship has identified logistics as a critical practice that no longer only buffers the friction of global trade but has 'remade geographies of capitalist production and distribution on a global scale' (Cowen 2OI4, p.IO), reconceptualising labour and citizenship within its spaces (Chua et al. 20I8). Singapore's rise as a logistical state was intimately tied to the shifting cartographies of global production and circulation in the second half of the 2oth century, leveraging its colonial legacy as an entrepot, already a prominent oil and rubber hub (Barr 2019). In labelling Singapore a logistical state, I build on Cowen's (2OI4) notion of the 'logistics city' - a new urban form central to the development of logistics in the 2 Ist century - to refer to forms of governance that manage and mitigate the demands of logistical operations of paramount importance to self-styled global city 'nodes' such as Singapore, which this chapter will examine through the city-state's management of migrant labour. These forms of governance, as will be demonstrated, depended on a patchwork of formal and informal policy mechanisms, where state-created zones of private contracting and subcontracting engineer systems allow for greater exploitation of labour, while the most flagrant excesses of this system can be dismissed as design failures. These ad hoc systems were engineered not just to limit the liability of the state but to ensure that key logistical systems and infrastructures are maintained without incident. While not the only dimension of the logistical state, as many other theorists of logistics have noted, the disciplining and regulating of labour in logistical operations has been tied to the inherent vulnerability of these systems (Cowen 20I4). Following Chua (20I7), I demonstrate that this logistical violence has entailed a concomitant logistical vulnerability in the form of a logistical virulence. Canny social and economic policies positioned the nascent city-state as a key manufacturing and logistical node in the region, with its swift development through the I970s and I980s powered by nimble switches along manufacturing value chains, outsourcing lower-value manufacturing to nearby Malaysia and Indonesia. The introduction of the Central 
Provident Fund (a mandatory savings and pensions programme), government-linked companies and banks, and sovereign wealth funds, as well as the vigorous pursuit of foreign direct investment and multi-national companies, formed the public face of Singapore's logistical-developmental trajectory, culminating in the paradoxical policy imaginary of a 'Singapore Model' (Chua 20II).

As Barr (2019) has noted, however, the role that low-paid migrant labour played in this transition has been almost comically underplayed: between 2004 and 2015 the number of foreign workers more than doubled, from $62 \mathrm{I}, 400$ to I, 368,200 , or $40 \%$ of the population. Foreign workers have served as a buffer, shielding the average Singaporean from the worst excesses of periodic unemployment (as employment passes can simply be revoked or reduced on an annual basis) and from the worst kinds of work and working conditions. The migrant worker, without any substantive political rights to reside or organise in Singapore, has been intimate with almost every facet of the production and reproduction of the logistical city-state:

Such foreign workers have built Singapore's factories, schools, skyscrapers, roads and railway lines [and] provided seemingly unlimited domestic service ... It is no exaggeration to say that Singapore's reliance upon cheap, vulnerable foreign labour has been at least as important to the country's economic development as more celebrated aspects of the political economy, such as its highly educated citizen workforce. (Barr 2019)

Low-wage migrant workers are unable to vote and are not allowed to collectively organise for better working conditions. They are excluded from the Employment Act, covered instead under the Employment of Foreign Manpower, and, owing to the lack of any fixed minimum wage in Singapore, are paid far lower than their Singaporean counterparts. Currently, Singapore has a foreign worker population of I.2 million, with nearly half classified as either foreign domestic workers or construction workers on work permits, the lowest-paid category of employment visa (MOM 2020). The fluctuating population of $300,000-$ odd migrant construction workers come from across South and Southeast Asia to make more money than they would at home. They fill the gap for dangerous and poorly paid labour that very few Singaporeans have to contemplate in facilitating the perpetual construction of the critical infrastructure of the logistical state, as well as its skyline and countless condominiums.

Singapore's successful brand of global city has been underwritten by overwhelming disparities between the subjects of its governance. 
In particular, the migrant worker has been the political subject of the logistical state. The distinction is important, as its citizens and expats (high-paid migrant labour) can vote and are accorded rights the migrant worker cannot access. While they are more intimately acquainted with the material production and reproduction of the city-state, they rarely encounter the state itself: migrant workers cannot apply directly for a work permit from the Ministry of Manpower but instead have to pay an agent to obtain one on their behalf for thousands of dollars. The agent then acts as a liaison between the Ministry of Manpower (more commonly referred to with the Freudian acronym MOM) and construction companies; the average Bangladeshi worker paid SG $\$ 6,400$ in agent fees in $20 \mathrm{I}_{5}$ (TWC2 20I8), not including an additional fee for the construction company to employ them. Workers seeking adequate compensation for workplace injuries and abuses are stymied by labyrinthine layers of bureaucracy that insulate contractors from subcontractors and can take years to rectify (TWC2 20I6).

The data on workplace injuries in the construction industry offers a grim if oblique view of the working conditions of the workers at most risk of injury; while the average ratio for recorded injuries to fatalities across $28 \mathrm{EU}$ member states in 20I 5 was 474:I (varying from 373:I in Sweden to I428: I in the Netherlands), for Singapore it was 82:I (TWC2 20I 8). This strongly suggests that injuries are persistently unrecorded, with several cases reported by Transient Workers Count Too (TWC2) and the Humanitarian Organization for Migration Economics demonstrating the extent to which doctors collaborate with construction companies to send injured labourers back to work. For the Ministry of Manpower, these events are aberrations that result from the informal nature of the migrant labour market, emerging as a natural consequence of competition and the desire for agents to obtain the best deals for the construction companies.

However, these aberrations and excesses have redirected attention from the inequalities structured into the migrant labour market itself and the political subjectivity cultivated by it. Bal (20I7) has aptly noted how these cases have been seized upon by the Ministry of Manpower as opportunities to theatrically perform their impartiality and concern, whereas the motivation for the specific kinds of exploitation and abuse faced by migrant workers has stemmed from the legal apparatus controlling migrant labour, such as the foreign worker levy. A complex legal and social system has thus kept migrants at risk to lubricate the capital circuits of the logistical state. Air and seaports, as well as dedicated petrochemical infrastructure, that have fortified Singapore's ongoing 
logistical relevance, were built and maintained by migrant workers that could not organise, conforming to Cowen's (20I4) hypothesis regarding the logistical recasting of labour and citizenship.

\section{Logistical citizenship}

Migrants' working and living conditions, seemingly the product of no grand design but rather an impromptu interlocking of design failures, redraw the lines of exploitation and precarity, prompting the question of whether these constitute the emergent conditions of a kind of 'logistical citizenship'. Cowen's (20I4) above-mentioned claim that shifts in circulation and logistics entailed a subsequent redrawing of the relations of the state to security, labour, and citizenship merits revisiting. The fragility of just-in-time supply chains necessitated new forms of governance and control commensurate with these territories of circulation (Cowen 20I4). The circulatory concerns of the logistical state point towards the desire to obscure not simply the labour that goes into its seamless functioning on the surface but to quarantine the very specific forms of political subjectivity it has constructed in the form of its class of migrant workers. By designing a class of workers insulated from the responsibility of the state through nested transnational chains of agents, middlemen, dormitory companies, contracting, and subcontracting, the state has inadvertently manufactured a political subject conditioned by the practice of logistics. This was made explicit following the security emergency of the 2013 Little India riot.

Singapore's 'bifurcated' regime of migrant labour, according to Yeoh (2006), is premised on a differential politics of inclusion and exclusion: for skilled, highly paid migrants, productivity and loyalty are rewarded with permanent residency and paths to citizenship; for the unskilled, no such route exists, and no matter how long they stay they will ultimately be 'transgressors' to be excluded (Yeoh 2006, p.36). This bifurcation was made a matter of formal government intervention in the aftermath of the Little India riot. In 20I3, a migrant construction worker relaxing in Little India, a district comprising the most central migrant worker dormitories and residences that also acts as a leisure hub for many other South Asian migrant workers, was run over and killed by a coach driver. The death prompted an immediate backlash from other workers nearby, resulting in a riot the likes of which Singapore had not seen since the race riots of 1969 (Lee et al. 20I 5). The riot ruptured the veneer of state-manufactured multi-ethnic harmony, with the politically 
invisible class of migrant workers becoming problematically present in the national consciousness.

The government was quick to dismiss the riot as an isolated, local event unrelated to the working and living conditions of the workers and focused instead on the predominantly South Asian workers' problematic consumption of alcohol and occupation of Little India on Sundays, as well as the perception of the neighbourhood as an 'area of "disamenity"' (Subramaniam 20I7, p.58). Alcohol was temporarily banned in Little India, and in the months and years to come the state would pursue a 'decentralisation' strategy, which saw the construction of additional migrant worker dormitories - gated facilities designed to accommodate tens of thousands of workers (Tan and Toh 20I4).

The construction and development of this new model of 'all-inclusive' migrant worker dormitory was developed as an explicit response to an unprecedented crisis of security for 2 Ist-century Singapore. Their haphazard attempts to wean migrant workers off the downtown core and leave them content and entertained at the periphery perversely mimicked the spatial contours of quarantine, and the discourse around the problematic presence of migrant workers within the city framed their transgression as a matter of public hygiene. While the permanent yet provisional presence of these migrant workers in the city was always regarded as a nuisance at best and a public health emergency at worst, what the riot and the immunological response to it made explicit was the pathologising of this class of worker by the state.

\section{Conclusion: logistical virulence}

The unbearable presence of Singapore's brand of logistical citizenship is a constitutive source of political and social unease because it points to the cracks within the Singapore model itself: beyond leveraging inequality, logistical citizenship is the political subject governed by the principles of logistics itself. Citizenship is informally rescaled by logistics to the raw input of labour-power, rendered 'efficient' by an opaque transnational market, and its presence is deemed pathological and in need of socio-spatial quarantine. While not an explicitly formulated class of citizen (beyond the regulations necessary for cultivating cheap and provisional sources of labour), what logistical citizenship holds for the political economy of the Singaporean state is not the jurisgenerative Roman spectre of Agamben's (I998) homo sacer, the bare life that can be exposed to death, but the exact kind of labour-power required by 
the considerable political-economic machinery of the logistical state. What has been legislated through logistical citizenship is not the calibration of the state of exception upon the expendable figure of bare life but the disciplining and governance of a product - labour - in the lubrication of capital circuits specific to chokepoints in global markets like shipping, petrochemicals, and construction. The pathological sociality of logistical citizenship needs to be contained and subject to legal-economic displacement so that the state's formal citizens do not encounter the true political-economic terms of their enduring prosperity.

The implicit logic of the sequestration was again made explicit by repeated coronavirus outbreaks in migrant worker dormitories; while citizens and permanent residents were subject to an exemplary response in pandemic control, those in the logistical state were exposed to exponential viral reproduction, with their mobility rendered pathological (Lin and Yeoh 202I). Here we find the perverse limit of the Singaporean state's ongoing experiment with an 'elastic notion of the scale of the nation and its citizenship' (Ong 2006, p.I78). It is no accident that the city-state's over-leveraging of low-paid migrant labour and desire to segregate it according to an implicit socio-immunological principle configured ideal circuits for viral reproduction. As Wallace et al. (2020) have noted, the COVID-I9 pandemic was conditioned by the circuits of capital themselves and the shifting economic geography of land use, agriculture, and enclosure and then reproduced globally by ubiquitous transport infrastructure. By linking logistical violence with virulence, we can then locate the outbreak of coronavirus in Singapore's migrant worker dormitories within the precarious construction of logistical citizenship itself.

\section{Acknowledgements}

I would like to thank the editors of this collection for putting together such a timely collection of articles on the impact of the coronavirus pandemic on Southeast Asia, and for their support and incisive comments that improved the chapter in numerous ways; any mistakes that remain are my own. I would also like to thank Robert John, who was the photographer of Figure II.I.

\section{References}

Agamben, Giorgio. (1998). Homo Sacer: Sovereign Power and Bare Life. Translated by D. Heller-Roazen. USA: Stanford University Press. 
Bal, Charan. (2017). 'Myths and facts: Migrant workers in Singapore'. New Naratif, 9 September. https://perma.cc/G8F3-ZWZD [Last accessed 28 January 2020].

Barr, Michael. (2019). 'Foundations laid, directions set'. New Naratif, 27 January. https://perma.cc/KUP7-EBJZ [Last accessed I 8 February 20I9].

Chew, M.H.; Koh, F.H.; Wu, J.T.; Ngaserin, S.; Ng, A.; Ong, B.C.; and Lee, V.J. (2020). 'Clinical assessment of COVID-I9 outbreak among migrant workers residing in a large dormitory in Singapore'. Journal of Hospital Infection, vol. I06, pp. 202-203.https://doi.org/IO.IOI6/j.jhin.2020.05.034

Chua, Beng Huat. (20I I). 'Singapore as model: Planning innovations, knowledge experts', in Ananya Roy and Aihwa Ong (eds) Worlding Cities: Asian Experiments and the Art of Being Global. UK: Wiley-Blackwell, pp. 27-54. https://doi.org/IO.I002/978 I444346800.ch I

Chua, Charmaine. (20I7). 'Logistical violence, logistical vulnerabilities'. Historical Materialism, vol. 25, pp. I67-I82. https://doi.org/IO.II63 II $569206 \mathrm{X}$-I 234 I 544

Chua, Charmaine; Danyluk, Martin; Cowen, Deborah; and Khalili, Laleh. (2018). 'Introduction: Turbulent circulation: Building a critical engagement with logistics'. Environment and Planning D: Society and Space, vol. 36, pp. 6I 7-629. https://doi.org/IO.I I 77/02637758 I 8783 IOI

Cowen, Deborah. (20I4). The Deadly Life of Logistics. USA: University of Minnesota Press.

Han, Kirsten. (2020). 'The cost of "Singapore Inc." ? A coronavirus outbreak among migrants'. The Nation, I7 August. https://perma.cc/F6QY-AVM6 [Last accessed I 5 May 202I].

Koh, David. (2020). 'Migrant workers and COVID-I9'. Occupational and Environmental Medicine, vol.77,no.9,pp.634-636.https://doi.org/Io. I 36 loemed-2020-106626

Lee, Wei Feng; Ooi, Chee Kheong; Phua, Dong Haur; Wong, Ming Hai Eric; Chan, Wui Ling; and Ng, Yih Yng. (20I 5). 'The Little India riot: Experience of an emergency department in Singapore'. Singapore Medical Journal, vol. 56, pp. 677-680. https://doi.org/Io.I I 622/smedj.20I 5 I 88

Lin, Weiqiang; and Yeoh, Brenda. (202I). 'Pathological (im)mobilities: Managing risk in a time of pandemics'. Mobilities, vol. I6, pp. 96-I I 2. https://doi.org/IO.IO80/I7450IOI.2020.I862454

MOM (Ministry of Manpower). (2020). Foreign Workforce Numbers. https:// perma.cc/L 5LZ-XD7P [Last accessed 29 April 202I]. 
Ong, Aihwa. (2006). Neoliberalism as Exception: Mutations in Citizenship and Sovereignty. USA: Duke University Press.

Sadarangani, Sapna P.; Lim, Poh Lian; and Vasoo, Shawn. (2017). 'Infectious diseases and migrant worker health in Singapore: A receiving country's perspective'. Journal of Travel Medicine, vol. 24, no. 4, pp. I-9. https://doi.org /IO.I093/jtm/taxoI4

Subramaniam, Gurubaran. (20I7). 'Evidence-based approaches to place management: Finding common ground in historic ethnic districts'. Urban Solutions, vol. I I, pp. 50-59.

Tan, Amelia; and Toh, Yong Chuan. (20I4). 'Cinema, cricket field at Singapore's biggest dormitory’. Straits Times, Io August. https://perma.cc/P5 T9-GVXA [Last accessed 2 December 2019].

TWC2. (2018). 'Recruitment cost in some cases about 20 times monthly sal-

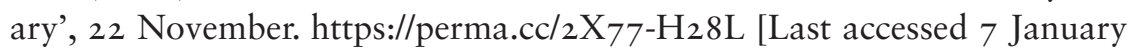
$202 \mathrm{I}]$.

TWC2. (2016). 'Workers who find their doctors and lawyers adding to their problems', I 8 September. https://perma.cc/J9KH-RS 4 U [Last accessed 7 January 202I].

Wallace, Rob; Liebman, Alex; Chaves, Fernando Luis; and Wallace, Rodrick. (2020). 'COVID-I9 and circuits of capital'. Monthly Review, I May. https:// perma.cc/4 RXJ-RFJ8 [Last accessed 27 August 2020].

Yea, Sallie. (2020). 'This is why Singapore's coronavirus cases are growing: A look inside the dismal living conditions of migrant workers'. The Conversation, 29 April. https://perma.cc/47A3-JUDG [Last accessed 25 August 2020].

Yeoh, Brenda. (2006). 'Bifurcated labour: The unequal incorporation of transmigrants in Singapore'. Tijdschrift voor economische en sociale geografie, vol. 97, pp. 26-37. https://doi.org/IO. I I I I/j.I 467-9663.2006.00493.X

Yeoh, Grace; and Smalley, Ruth. (2020). 'Recovered from COVID-I9, migrant workers live on a cruise ship and in an HDB flat'. CNA, 23 May. https:// perma.cc/A9Q3-GBZB [Last accessed 6 August 2020]. 